Short communication

\title{
Upwelling spike and marked SST drop after the arrival of cyclone Dorian to the Atlantic Canadian coast
}

\author{
Ricardo A. Scrosati \\ St. Francis Xavier University, Department of Biology, 2320 Notre Dame Ave., Antigonish, Nova Scotia B2G 2W5, Canada
}

A R T I C L E I N F O

\section{Keywords:}

Cyclone

Hurricane

Intertidal

NW Atlantic

Sea surface temperature

SST

\begin{abstract}
A B S T R A C T
In intertidal environments, temperature changes at hourly scales are ecologically relevant because of the physiological stress that organisms must endure as a result. Tides constitute the main source of such changes, as low tides periodically expose intertidal habitats to aerial conditions, which can exhibit extreme high and low temperatures in summer and winter, respectively. This study identifies a source of strong hourly thermal variation that acts upon seawater temperature. Hours after the arrival of cyclone Dorian to the Atlantic Canadian coast in September 2019, intertidal loggers revealed that sea surface temperature (SST) decreased by $10-12{ }^{\circ} \mathrm{C}$. Online data indicated that neither tidal amplitude nor air temperature were responsible for this marked SST drop. Conversely, data on wind speed and direction strongly suggest that a pronounced spike in coastal upwelling caused by this cyclone drove the sharp drop in intertidal SST. Bakun's upwelling index, for instance, peaked at $689 \mathrm{~m}^{3} \mathrm{~s}^{-1}$ (100 $\mathrm{m}$ of coastline $)^{-1}$ a few hours after Dorian's landfall. It remains to be seen how this marked SST drop may have affected intertidal organisms, as they were then acclimated to summer conditions. As the frequency and intensity of cyclones are predicted to increase with climate change in temperate latitudes, cyclonerelated intertidal thermal ecology might deserve further attention.
\end{abstract}

\section{Introduction}

In intertidal habitats, temperature can vary considerably at temporal scales of hours. Understanding the causes of such changes is important because abiotic variability can be as ecologically relevant as mean conditions (Bennedetti-Cecchi et al., 2006; Somero, 2007). Tides have long been recognized as a central factor influencing intertidal temperature at hourly scales (Helmuth et al., 2002; Finke et al., 2007). The reason is that low tides periodically expose intertidal habitats to aerial conditions, which exhibit temperatures that may greatly differ from seawater temperature. In particular, intertidal temperature during low tides can reach extreme values on hot days in spring and summer (Lathlean et al., 2014; Umanzor et al., 2017) and cold days in winter (Scrosati, 2011). Factors such as macroalgal cover (Watt and Scrosati, 2013; Scrosati and Ellrich, 2018) and a stable cover of ice (Scrosati and Eckersley, 2007) can limit such thermal extremes.

Other short-term changes in intertidal temperature are caused by factors that influence only seawater temperature. For example, coastal upwelling can drive deep, cool waters to the surface in a matter of hours, in that way cooling intertidal environments during high tides (Tapia et al., 2009). Coastal upwelling is common in many parts of the world and is frequently driven by alongshore winds in concert with Coriolis forcing (Kämpf and Chapman, 2016). Cyclones are extreme cases of wind forcing. Given their capacity for vertical mixing of upper ocean layers (Seroka et al., 2016; Liu et al., 2018), cyclones might also generate significant thermal fluctuations in intertidal habitats at hourly scales. However, this seems not to have been examined quantitatively, probably because of the low frequency of occurrence of coastal cyclones in comparison with tides and regular upwelling events. To address this knowledge gap, the present study investigates the marked intertidal cooling that occurred on the Atlantic Canadian coast with the arrival of cyclone Dorian in 2019.

\section{Materials and methods}

Dorian approached Canada as a hurricane from southern waters, making landfall on the Canadian coast as a post-tropical cyclone near Halifax (Nova Scotia) at 19:15, local time (Atlantic Daylight Time = UTC-3), on 7 September 2019 (AccuWeather, 2019; NOAA, 2020). To evaluate Dorian's effects on intertidal temperature on the Nova Scotia coast, this study uses data on sea surface temperature (SST) measured at two intertidal locations separated by $43 \mathrm{~km}$ : Deming Island (N 45.2121, W 61.1738) and Barachois Head (N 45.0890, W 61.6933; Fig. 1). Both are wave-exposed locations, facing the open waters of the Atlantic Ocean without any physical obstructions. The substrate of both locations is stable bedrock. To make Dorian's thermal signal most

E-mail address: rscrosat@stfx.ca. 


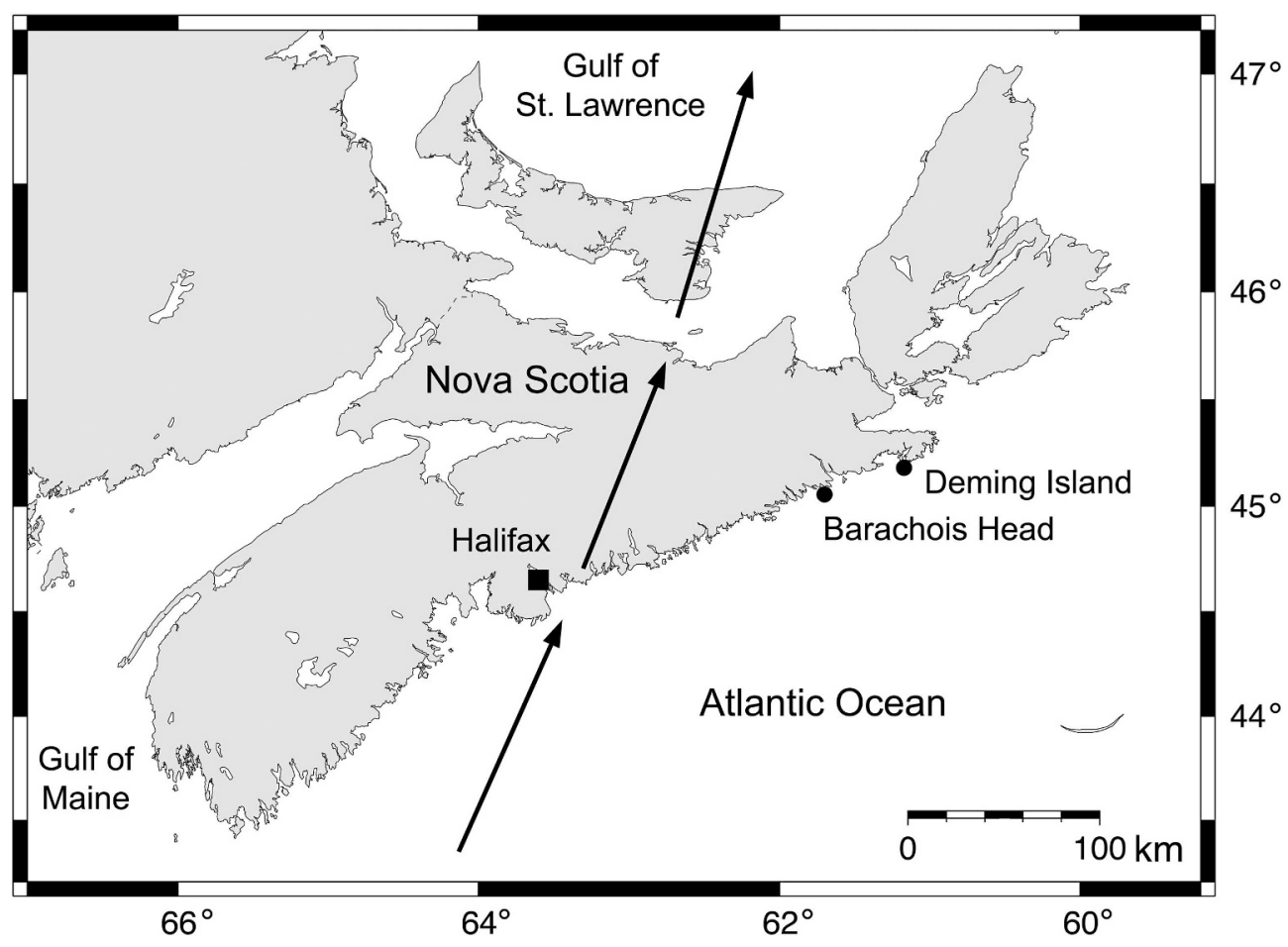

Fig. 1. Map of Nova Scotia, showing the position of the two studied intertidal locations (Deming Island and Barachois Head) and the path of cyclone Dorian's centre (arrows).

evident, SST data measured between 1 and 16 September 2019 are hereby used.

At each location, SST was measured with a submersible logger (HOBO Pendant logger, Onset Computer, Bourne, MA, USA) that was permanently attached to the intertidal substrate by plastic cable ties secured to eye screws drilled into the substrate, allowing almost no contact between the logger and the substrate. The loggers recorded temperature every $30 \mathrm{~min}$. From the two resulting time series, values describing SST were extracted. For this purpose, first the time of the successive peaks of high tide was determined for each location using information from the tide reference stations that are closest to the studied locations: Whitehead (N 45.2333, W 61.1833) for Deming Island and Port Bickerton (N 45.1000, W 61.7333) for Barachois Head (Tide and Current Predictor, 2020). Then, the temperature value recorded by each logger closest to the time of each high tide was extracted and considered as SST. Such values reliably describe SST because even the lowest high tides found for the study period $(1.3 \mathrm{~m}$ at Deming Island and $1.4 \mathrm{~m}$ at Barachois Head, above chart datum) were higher than the intertidal elevation where the loggers were attached to, indicating that both loggers were submerged when such temperature values were recorded. The resulting dataset on intertidal SST is available from the figshare online repository (Scrosati, 2019).

To examine how Dorian's winds reached the studied intertidal locations, data on hourly wind speed and daily maximum gusts were retrieved for the weather stations that are closest to the studied intertidal locations: Hart Island (N 45.35, W 60.98) for Deming Island and Beaver Island (N 44.82, W 62.33) for Barachois Head (Government of Canada, 2020). Hourly values of wind speed represent the average speed during the one-, two-, or ten-minute period ending at the time of observation (Government of Canada, 2020). To examine the influence of winds on coastal upwelling during the studied period, hourly data on wind direction were also retrieved from those two weather stations (Government of Canada, 2020). Then, using the data on wind speed and direction, Bakun's upwelling index (UI) was calculated hourly for Deming Island and Barachois Head for the entire study period. The steps followed to calculate UI have been detailed elsewhere (Scrosati and Ellrich, 2020) and consider a general orientation of the studied coast of $70^{\circ}$ relative to the north. In this study, UI is expressed as cubic meters of seawater transported per second per $100 \mathrm{~m}$ of coastline. Positive UI values indicate upwelling, whereas negative UI values indicate downwelling (Kämpf and Chapman, 2016).

To exclude tidal amplitude as a possible explanation for the SST drop measured shortly after Dorian (see Results), the height of the highest tide of each day (proxy for tidal amplitude) was retrieved for Whitehead and Port Bickerton (Tide and Current Predictor, 2020), under the notion that coastal SST changes are favoured by spring tides (instead of neap tides) due to increased mixing (Kang and Lee, 2014; Shanks et al., 2014; Iwasaki et al., 2015). To exclude air temperature as a potential explanation for the SST drop measured shortly after Dorian, data on hourly air temperature were retrieved for Hart Island and Beaver Island (Government of Canada, 2020).

\section{Results}

Before Dorian's landfall on the Canadian coast on 7 September, SST exhibited relatively small changes from day to day, staying between 19 and $20^{\circ} \mathrm{C}$ at Deming Island and $17-21{ }^{\circ} \mathrm{C}$ at Barachois Head (Figs. 2-3). After Dorian's arrival, however, SST dropped sharply and quickly at both locations, reaching $9.7^{\circ} \mathrm{C}$ at Deming Island and $6.8^{\circ} \mathrm{C}$ at Barachois Head at 18:30 (local time) on 8 September (Figs. 2-3). By 9 September, SST reached higher levels again, but stayed only around $15{ }^{\circ} \mathrm{C}$ at Deming Island and mostly between 12 and $17{ }^{\circ} \mathrm{C}$ at Barachois Head for the remainder of the study (Figs. 2-3).

Coastal surface winds barely surpassed $40 \mathrm{~km} \mathrm{~h}^{-1}$ before 7 September (Figs. 2-3). However, during 7 September, winds intensified dramatically as Dorian's centre reached the shore, reaching hourly values of $88 \mathrm{~km} \mathrm{~h}^{-1}$ near Deming Island and $106 \mathrm{~km} \mathrm{~h}^{-1}$ near Barachois Head (Figs. 2-3), with gusts up to $126 \mathrm{~km} \mathrm{~h}^{-1}$ near Deming Island and $145 \mathrm{~km} \mathrm{~h}^{-1}$ near Barachois Head. After Dorian left the region, and for the remainder of this study, values of wind speed remained similar to those measured before this cyclone (Figs. 2-3).

Before 7 September, UI was relatively low, with a highest value of 

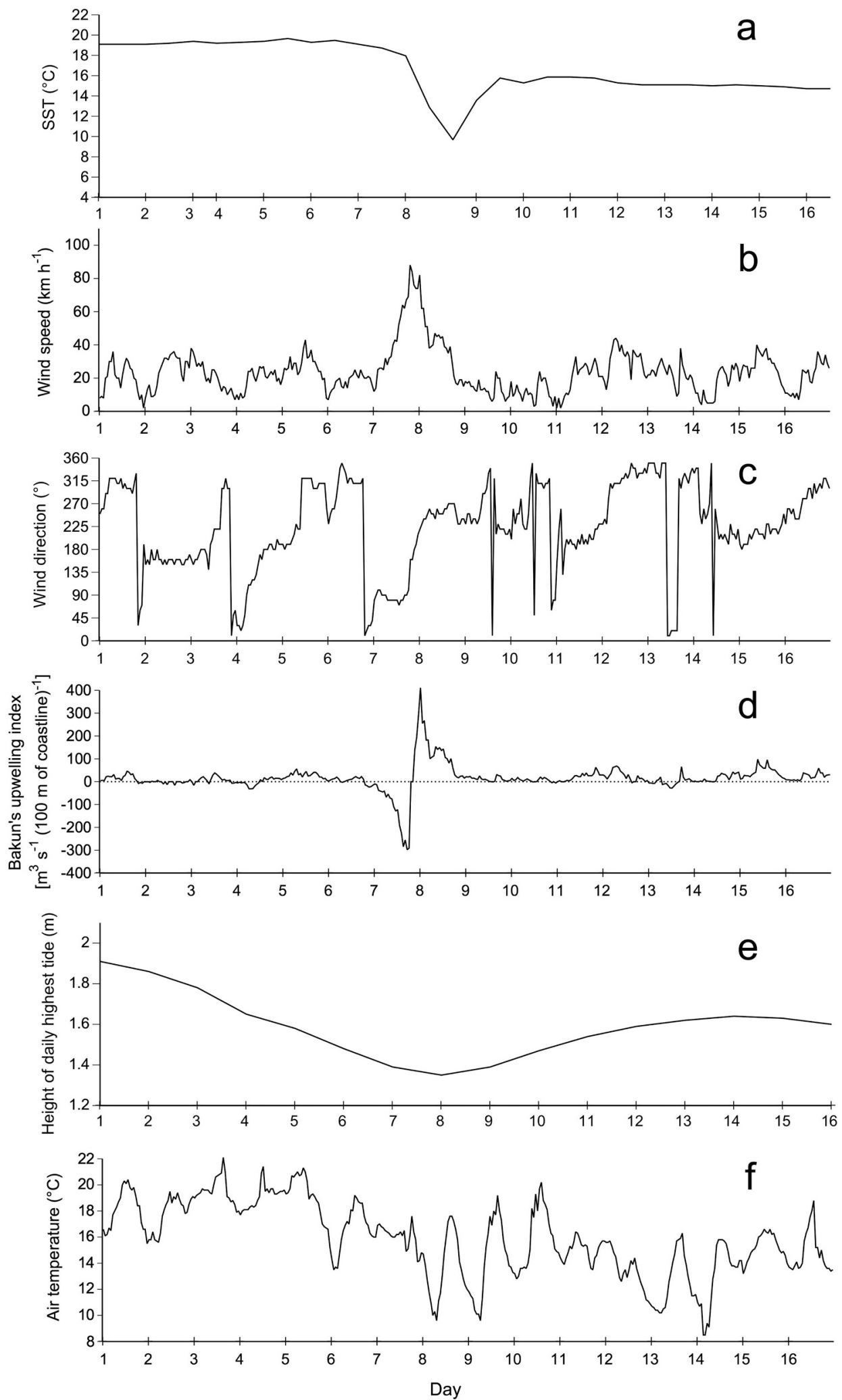

Fig. 2. Environmental trends for Deming Island between 1 and 16 September 2019: (a) intertidal sea surface temperature (SST, measured during high tides), (b) wind speed, (c) wind direction (angle measured clockwise from the north $-0^{\circ}$ - indicating the direction where the wind came from), (d) Bakun's upwelling index, (e) height of the daily highest tide (proxy for tidal amplitude), and (f) air temperature. SST data for 8 September also include the lowest SST value found for that day, which was recorded $2 \mathrm{~h}$ after the second high tide of that day while the logger was still submerged.

only $56 \mathrm{~m}^{3} \mathrm{~s}^{-1}$ (100 $\mathrm{m}$ of coastline) $)^{-1}$ for Deming Island and $88 \mathrm{~m}^{3} \mathrm{~s}^{-1}$ $(100 \mathrm{~m} \text { of coastline })^{-1}$ for Barachois Head (Figs. 2-3). On 7 September until Dorian's centre made landfall, UI exhibited negative values at both locations. However, after Dorian's landfall, UI increased rapidly and exhibited a peak of $411 \mathrm{~m}^{3} \mathrm{~s}^{-1}$ (100 $\mathrm{m}$ of coastline) $)^{-1}$ at 24:00 (local time) at Deming Island and $689 \mathrm{~m}^{3} \mathrm{~s}^{-1}$ (100 $\mathrm{m}$ of coastline $)^{-1}$ at 22:00 

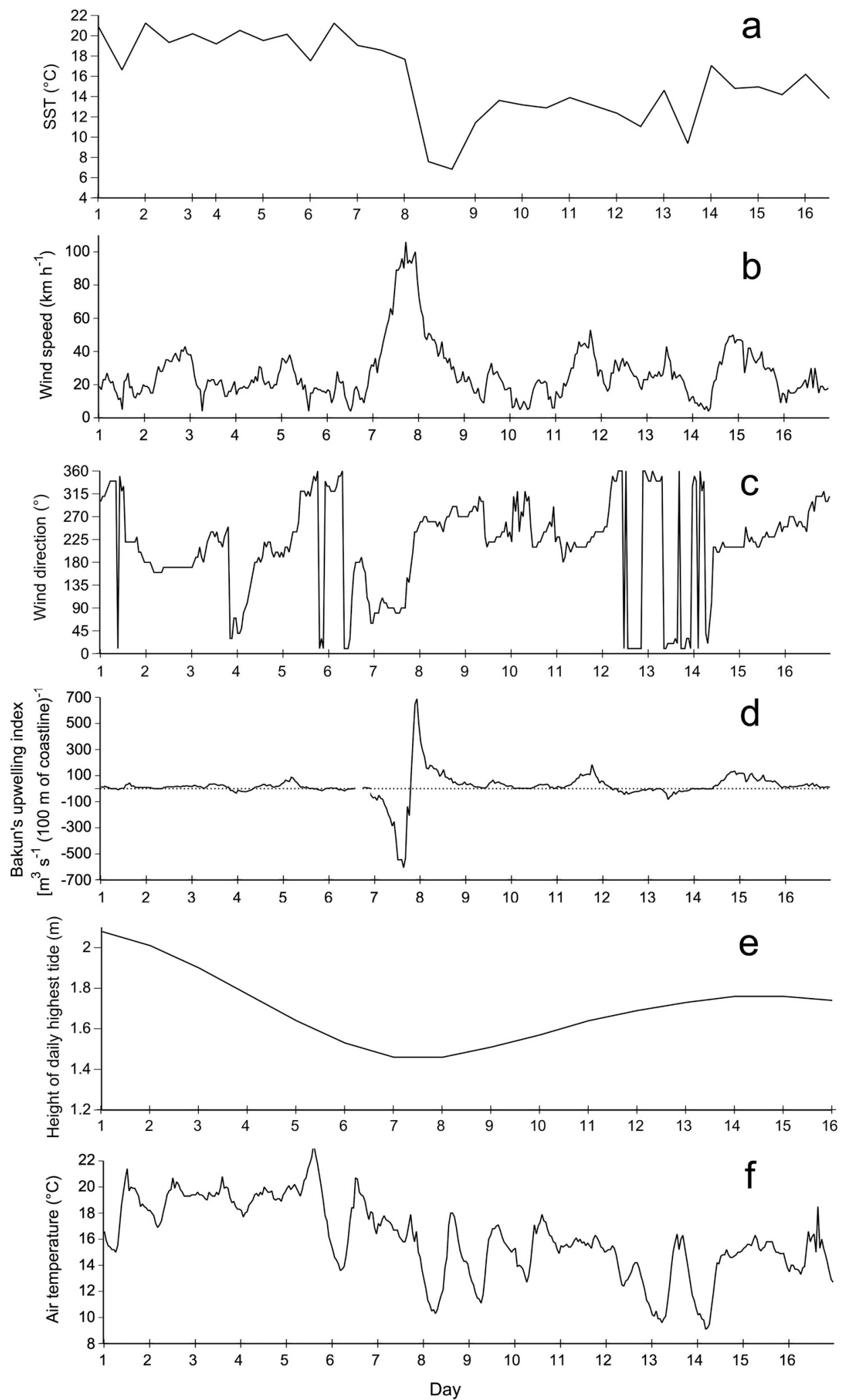

Fig. 3. Environmental trends for Barachois Head between 1 and 16 September 2019: (a) intertidal sea surface temperature (SST, measured during high tides), (b) wind speed, (c) wind direction (angle measured clockwise from the north $-0^{\circ}$ - indicating the direction where the wind came from), (d) Bakun's upwelling index, (e) height of the daily highest tide (proxy for tidal amplitude), and (f) air temperature. SST data for 8 September also include the lowest SST value found for that day, which was recorded $2 \mathrm{~h}$ after the second high tide of that day while the logger was still submerged.

(local time) at Barachois Head on 7 September (Figs. 2-3). UI decreased progressively at both locations during 8 September, although still exhibiting higher values than between 1 and 6 September (Figs. 2-3).
After 8 September, UI remained relatively low again (Figs. 2-3).

The passage of Dorian through the studied region during 7-8 September coincided with neap tides, not spring tides (Figs. 2-3). Both 
before 7 September and after 8 September, air temperature often decreased during night hours (Figs. 2-3) but, as noted above, SST remained relatively stable during both such periods, especially at Deming Island. Thus, air temperature seems not to have played any significant role in SST changes. In fact, the marked drop in SST that occurred after Dorian took place mainly during daytime on 8 September and, thus, largely coincided with an increase in air temperature.

\section{Discussion}

The present study has identified a marked drop of SST in intertidal environments on the open Atlantic coast of Nova Scotia shortly after cyclone Dorian made landfall. During the $24 \mathrm{~h}$ after the centre of this cyclone reached the coast, intertidal SST decreased by $10-12{ }^{\circ} \mathrm{C}$. This is a stronger decrease in SST than those caused within one day (up to $6^{\circ} \mathrm{C}$ ) by regular wind-driven upwelling on the Nova Scotia coast in summer (Scrosati and Ellrich, 2020). In fact, the SST drop observed after Dorian rivals intertidal thermal drops caused by exposure to the air during low tides in cold winter days, which can decrease intertidal temperature (which remains near $0{ }^{\circ} \mathrm{C}$ during high tides) by up to $14{ }^{\circ} \mathrm{C}$ when air temperature is low enough on the Nova Scotia coast (Scrosati, 2011). These are valuable results because they are based on in-situ SST data, as opposed to satellite SST data, which are often less accurate (Smale and Wernberg, 2009) and sometimes even unavailable for some days.

The tide and air temperature data revealed that neither tidal amplitude nor air temperature were likely responsible for the strong intertidal SST drop recorded on 8 September. On marine shores, the highest tidal amplitudes occur during periods of spring tides. Compared with neap tides, spring tides can favour the cooling of coastal surface waters due to increased vertical mixing (Kang and Lee, 2014; Shanks et al., 2014; Iwasaki et al., 2015). However, on the studied coast, SST changes were either small (Barachois Head) or unnoticeable (Deming Island) during spring tides, suggesting a negligible influence, if any, of neap tides on SST. As the marked SST drop of 8 September occurred during neap tides, tidal amplitude then seems to have played little-to-no influence, a conclusion that was also reached for offshore SST decreases in relation to hurricane activity (Miles et al., 2017). Regarding air temperature, the marked intertidal SST drop of 8 September occurred mostly during daytime, thus largely coinciding with an increase in air temperature. In fact, similar daytime increases in air temperature were common during the study period. Thus, air temperature seems not to have played any major role in the pronounced decrease of intertidal SST after Dorian either.

The wind data strongly indicate that cyclone Dorian was, in fact, the cause of the marked decrease of intertidal SST on 8 September. At lower latitudes, tropical hurricanes decrease SST in offshore environments due to shear-induced vertical mixing of waters, as subsurface layers of the ocean are typically cooler than surface layers, especially in summer (Korobkin et al., 2009; Lai et al., 2015; Glenn et al., 2016; Seroka et al., 2016; Liu et al., 2018). The timing of the sharp SST drop observed after the passage of Dorian agrees with observations made for tropical hurricanes (Rao et al., 2004). Shear-induced vertical mixing of waters could thus have contributed to the observed SST drop. At the same time, the UI values calculated for both studied locations suggest that wind-driven upwelling played a central role in the marked SST drop. In fact, in the late hours of 7 September, shortly after Dorian's landfall, UI peaked at values that were $734 \%$ and $783 \%$ higher (at Deming Island and Barachois Head, respectively) than the highest UI values recorded before Dorian's arrival between 1 and 6 September. Interestingly, by 9 September, intertidal SST increased again and regained pre-Dorian levels of temporal stability, but staying on average $4-5{ }^{\circ} \mathrm{C}$ lower than before Dorian. This pattern is in line with an inertial mixing period after direct cyclone forcing (Rao et al., 2004).

The consequence of such a sharp drop in SST on the physiology of intertidal organisms is unknown, but it may not be small given that the cyclone occurred in summer, when organisms are acclimated to relatively warm air and water temperatures. As cyclone activity is expected to grow in intensity with climate change in temperate latitudes (Knutson et al., 2013; Kossin et al., 2014), cyclone-related intertidal thermal ecology might deserve further attention.

\section{Author contributions}

R.A.S. is the single author of this study.

\section{Acknowledgements}

The author is grateful to anonymous reviewers for constructive comments on an earlier version of the manuscript. This study was funded by a Discovery Grant (number 311624) from the Natural Sciences and Engineering Research Council (NSERC) and by a Leaders Opportunity Grant (number 202034) from the Canada Foundation for Innovation (CFI) awarded to the author. The funding sources had no involvement in study design or in the collection, analysis, and interpretation of the data.

\section{References}

AccuWeather, 2019. Dorian made 6th landfall at Nova Scotia; thousands without power. https://www.accuweather.com/en/weather-news/dorain-made-5th-landfall-as-itreaches-nova-scotia/70009277 Accessed 17 December 2019.

Bennedetti-Cecchi, L., Bertocci, I., Vaselli, S., Maggi, E., 2006. Temporal variance reverses the impact of high mean intensity of stress in climate change experiments. Ecology $87,2489-2499$.

Finke, G.R., Navarrete, S.A., Bozinovic, F., 2007. Tidal regimes of temperate coasts and their influences on aerial exposure for intertidal organisms. Mar. Ecol. Prog. Ser. 343 57-62.

Glenn, S.M., Miles, T.N., Seroka, G.N., Xu, Y., Forney, R.K., Yu, F., Roarty, H., Schofield, O., Kohut, J., 2016. Stratified coastal ocean interactions with tropical cyclones. Nat. Commun. 7, article 10887.

Government of Canada, 2020. Past Weather and Climate. Historical data. http://climate. weather.gc.ca/historical_data/search_historic_data_e.html Accessed 14 February 2020 .

Helmuth, H., Harley, C.D.G., Halpin, P.M., O'Donnell, M., Hofmann, G.E., Blanchette, C.A., 2002. Climate change and latitudinal patterns of intertidal thermal stress. Science 298, 1015-1017.

Iwasaki, S., Isobe, A., Miyao, Y., 2015. Fortnightly atmospheric tides forced by spring and neap tides in coastal waters. Sci. Rep. 5, article 10167.

Kämpf, J., Chapman, P., 2016. Upwelling systems of the world. A Scientific Journey To The Most Productive Marine Ecosystems. Springer, Cham.

Kang, K.R., Lee, S.R., 2014. Variation of the summer low SST area in the southwestern coast of Korea. Geosci. J. 18, 231-239.

Knutson, T.R., Sirutis, J.J., Vecchi, G.A., Garner, S., Zhao, M., Kim, H.S., Bender, M., Tuleya, R.E., Held, I.M., Villarini, G., 2013. Dynamical downscaling projections of twenty-first-century Atlantic hurricane activity: CMIP3 and CMIP5 model-based scenarios. J. Clim. 26, 6591-6617.

Korobkin, M., D'Sa, E., Ko, D.S., 2009. Satellite observations and NCOM assessment of the Mississippi-Louisiana-Texas coast following hurricanes Gustav and Ike. In: Naval Research Laboratory. Stennis Space Center, MS, USA Report No. NRL/PP/7320-099322.

Kossin, J.P., Emanuel, K.A., Vecchi, G.A., 2014. The poleward migration of the location of tropical cyclone maximum intensity. Nature 509, 349-352.

Lai, Q.Z., Wu, L.G., Shie, C.L., 2015. Sea surface temperature response to typhoon Morakot (2009) and its influence. J. Trop. Meteorol. 21, 111-120.

Lathlean, J.A., Ayre, D.J., Minchinton, T.E., 2014. Estimating latitudinal variability in extreme heat stress on rocky intertidal shores. J. Biogeogr. 41, 1478-1491.

Liu, Y., Weisberg, R.H., Law, J., Huang, B., 2018. Evaluation of satellite-derived SST products in identifying the rapid temperature drop on the West Florida Shelf associated with hurricane Irma. Mar. Technol. Soc. J. 52, 43-50.

Miles, T., Seroka, G., Glenn, S., 2017. Coastal ocean circulation during hurricane Sandy. J. Geophys. Res.: Oceans 122, 7095-7114.

NOAA, 2020. National Oceanic and Atmospheric Administration. Historical hurricane tracks. https://coast.noaa.gov/hurricanes Accessed 14 February 2020.

Rao, A.D., Babu, S.V., Dube, S.K., 2004. Impact of a tropical cyclone on coastal upwelling processes. Nat. Hazards 31, 415-435.

Scrosati, R.A., 2011. Subarctic shores without an ice foot: low extremes in intertidal temperature during winter. Curr. Dev. Oceanogr. 3 (2), 153-160. https://doi.org/10. 31230/osf.io/khdc2.

Scrosati, R.A., 2019. Intertidal SST data for the Nova Scotia coast (September 2019). figshare dataset. https://doi.org/10.6084/m9.figshare.11312774.v2. Accessed 19 February 2020.

Scrosati, R., Eckersley, L.K., 2007. Thermal insulation of the intertidal zone by the ice foot. J. Sea Res. 58, 331-334.

Scrosati, R.A., Ellrich, J.A., 2018. Thermal moderation of the intertidal zone by seaweed canopies in winter. Mar. Biol. 165, article 115. 
Scrosati, R.A., Ellrich, J.A., 2020. Marked contrast in wind-driven upwelling on the southeastern Nova Scotia coast in July of two years differing in ENSO conditions. Oceanol. Hydrobiol. Stud. 49, 81-87.

Seroka, G., Miles, T., Xu, Y., Kohut, J., Schofield, O., Glenn, S., 2016. Hurricane Irene sensitivity to stratified coastal ocean cooling. Mon. Weather Rev. 144, 3507-3530.

Shanks, A.L., Morgan, S.G., MacMahan, J., Reniers, A.J.H.M., Jarvis, M., Brown, J., Fujimura, A., Griesemer, C., 2014. Onshore transport of plankton by internal tides and upwelling-relaxation events. Mar. Ecol. Prog. Ser. 502, 39-51.

Smale, D.A., Wernberg, T., 2009. Satellite-derived SST data as a proxy for water temperature in nearshore benthic ecology. Mar. Ecol. Prog. Ser. 387, 27-37.

Somero, G., 2007. Heat stress. In: Denny, M.W., Gaines, S.D. (Eds.), Encyclopedia of Tidepools and Rocky Shores. University of California Press, Berkeley, pp. 266-270.
Tapia, F.J., Navarrete, S.A., Castillo, M., Menge, B.A., Castilla, J.C., Largier, J., Wieters, E.A., Broitman, B.L., Barth, J.A., 2009. Thermal indices of upwelling effects on innershelf habitats. Prog. Oceanogr. 83, 278-287.

Tide and Current Predictor, 2020. Tidal height and current site selection. http://tbone. biol.sc.edu/tide/index.html Accessed 14 February 2020.

Umanzor, S., Ladah, L., Calderón-Aguilera, L.E., Zertuche-González, J.A., 2017. Intertidal macroalgae influence macroinvertebrate distribution across stress scenarios. Mar. Ecol. Prog. Ser. 584, 67-77.

Watt, C.A., Scrosati, R.A., 2013. Bioengineer effects on understory species richness, diversity, and composition change along an environmental stress gradient: experimental and mensurative evidence. Estuar. Coast. Shelf Sci. 123, 10-18. 